IZA DP No. 7234

Happiness, Growth, and Public Policy

Richard A. Easterlin

February 2013 


\title{
Happiness, Growth, and Public Policy
}

\author{
Richard A. Easterlin \\ University of Southern California \\ and IZA
}

\section{Discussion Paper No. 7234 \\ February 2013}

\author{
IZA \\ P.O. Box 7240 \\ 53072 Bonn \\ Germany \\ Phone: +49-228-3894-0 \\ Fax: +49-228-3894-180 \\ E-mail: iza@iza.org
}

Any opinions expressed here are those of the author(s) and not those of IZA. Research published in this series may include views on policy, but the institute itself takes no institutional policy positions. The IZA research network is committed to the IZA Guiding Principles of Research Integrity.

The Institute for the Study of Labor (IZA) in Bonn is a local and virtual international research center and a place of communication between science, politics and business. IZA is an independent nonprofit organization supported by Deutsche Post Foundation. The center is associated with the University of Bonn and offers a stimulating research environment through its international network, workshops and conferences, data service, project support, research visits and doctoral program. IZA engages in (i) original and internationally competitive research in all fields of labor economics, (ii) development of policy concepts, and (iii) dissemination of research results and concepts to the interested public.

IZA Discussion Papers often represent preliminary work and are circulated to encourage discussion. Citation of such a paper should account for its provisional character. A revised version may be available directly from the author. 
IZA Discussion Paper No. 7234

February 2013

\section{ABSTRACT}

\section{Happiness, Growth, and Public Policy*}

If society's goal is to increase people's feelings of well-being, economic growth in itself will not do the job. Full employment and a generous and comprehensive social safety net do increase happiness. Such policies are arguably affordable not only in higher income nations but also in countries that account for most of the population of the less-developed world. These conclusions are suggested by an analysis of a wide range of evidence on happiness in countries throughout the world.

JEL Classification: $\quad$ I31, I38, O21, F20, D60, E60

Keywords: happiness, life satisfaction, subjective well-being, economic growth, safety net policies, developed countries, transition countries, less developed countries, China

Corresponding author:

Richard A. Easterlin

Department of Economics

KAP 318B

University of Southern California

Los Angeles, CA 90089-0253

USA

E-mail: easterl@usc.edu

\footnotetext{
Presidential address, Western Economic Association International, July 1, 2012. (C) Western Economic Association International. Reprinted with permission from Economic Inquiry, Vol. 51, No. 1, January 2013, pages 1-15, DOI: 10.1111/j.1465-7295.2012.00505.x.

I am grateful to Robson Morgan and Malgorzata Switek for valuable assistance, and to Paul David and Lucien Bebchuk for helpful comments. The University of Southern California provided financial assistance.
} 


\section{INTRODUCTION}

Happiness as a measure of well-being is gradually becoming more accepted by economists and policy makers ${ }^{1}$. It seems appropriate, therefore, to examine some of its implications for public policy. I will address three specific questions:

1. Are economic growth policies sufficient in themselves to raise people's happiness, i.e. their subjective well-being (SWB)?

2. Are there other policies that might raise SWB?

3. Can poorer countries afford policies to raise SWB?

My approach, in answering these questions, is to draw on the available evidence, based partly on the happiness literature and partly on my own collaborative research. The answers suggested by the evidence are respectively, no, yes, and yes.

I take as the measure of economic growth, the usual one, real gross domestic product (GDP) per capita. Mean SWB is calculated here as the average of individuals' integer responses to survey questions of the type listed in Table 1 . The terms subjective well-being, happiness, and life satisfaction are used interchangeably; though not identical in concept, they are closely related (Easterlin 2010, 8-9, 103-104).

Until recently, economists assumed that measures of an individual's external (observable) circumstances, especially one's income, were sufficient to assess wellbeing, and self-reports of subjective feelings were dismissed out of hand ${ }^{2}$. The 2008 Stiglitz-Sen-Fitoussi Report, commissioned by French President Sarkozy to propose more meaningful measures of well-being, is indicative of the sea-change that has 
taken place. After advocating the official collection of a variety of objective measures, the Report of the 25-member Commission (including 5 Nobel prize winners in economics) states:

Research has shown that it is possible to collect meaningful and reliable data on subjective as well as objective well-being.... [T] he types of questions that have proved their value within small-scale and unofficial surveys should be included in larger scale surveys undertaken by official statistical offices. (Stiglitz, Sen, and Fitoussi, 2008, 16)

The SWB measures used here are among the principal ones advocated in the report.

\section{DOES GROWTH RAISE HAPPINESS?}

The long term relationship - The answer to this question is often based on the bivariate cross section relation of happiness to real GDP per capita. A frequently cited example is Angus Deaton's (2008) analysis of Gallup World Poll data for 123 countries. Deaton's Figure 2 (p. 57) is reproduced in full here (Figure 1) $)^{3}$. The inference suggested by the figure is stated explicitly in Deaton's boldface title: "Each Doubling of GDP is Associated with a Constant Increase in Life Satisfaction." This generalization is found by Deaton to apply across the income stratum, with the relationship being, if anything, stronger in richer than in poorer countries. For real world growth rates of GDP per capita, say up to 10 percent per year, Deaton's generalization implies that doubling the growth rate of GDP per capita will approximately double the increment in life satisfaction.

Of course, the test of this cross section relationship is whether it holds true in historical experience. To evaluate this, I present here the results of several time 
series studies covering recent decades done by my collaborators and me. The countries included are those with a fairly long time span of comparable SWB data, usually a minimum of 12 years but often much more ${ }^{4}$. For each country we compute the growth rate of real GDP per capita over the full time span of SWB data, and the corresponding increment in SWB. We then compare the observations for the various countries to see whether countries with higher rates of economic growth have significantly higher increments in subjective well-being - at the extreme, whether doubling the growth rate of GDP doubles the increment in life satisfaction. This is, of course, only a bivariate analysis, but so too are the cross section studies, like Deaton's, on which generalizations are based about the effect of economic growth on happiness. The results here are quite consistent and easily summarized:

1. For 17 developed countries with time series ranging from 21 to 34 years, there is no significant relationship between the rate of improvement in life satisfaction and the growth rate of GDP per capita (Figure 2). The countries included here are fourteen developed countries of Europe plus the United States, Canada, and Australia. For most countries the long term GDP growth rates are between 1.5 and 3 per cent, but for two, Ireland and Luxembourg, the rates are between 3 and 5 per cent. If Ireland and Luxembourg are deleted, there is still no significant relationship, as can readily be seen from a glance at Figure 2.

2. For 9 developing countries with time series ranging from 15 to 33 years, there is no significant relationship between the rate of improvement in happiness and rate of economic growth (Figure 3). The nine countries are 
typically fairly populous, four in Asia, four in Latin America, and one in subSaharan Africa. The economic growth rates range from around zero for South Africa to almost 10 per cent per year for China. If China, the outlier of the group, is omitted, the regression coefficient remains not significant. 3. For 11 transition countries with time series ranging from 12 to 22 years, there is no significant relationship between the improvement in life satisfaction and the rate of economic growth (Figure 4). The eleven countries range across central and eastern Europe and are those for which there is a life satisfaction observation near the start of the transition (cf. Easterlin 2010, 86). Their economic growth rates are from slightly negative to about 3 per cent per year.

4. For all 37 countries taken together, with time series ranging from 12 to 34 years in length, there is no significant relation between the improvement in life satisfaction and the rate of economic growth (Figure 5). The growth rates of GDP per capita typically range from slightly negative to almost 6 per cent. If the one outlier, China, is omitted, the regression coefficient is still not significant.

In sum, for rich, poor, and transition countries, whether pooled or analyzed separately, there is no evidence that a higher growth rate increases the rate of improvement in life satisfaction. Doubling the rate of economic growth does not double the increase in life satisfaction; rather, the evidence is that it has no significant effect at all. 
Reasonably comparable time series data on SWB in less developed countries are in short supply. In the foregoing analysis, the World Values Survey (WVS) was the principal source and it was possible to include only nine less developed countries. Fortunately the annual Latinobarometer surveys, covering 17 Latin American countries since 1994, provide an additional body of data on the experience of lower income nations. The life satisfaction question in these surveys changes too frequently to be used, but the question on financial satisfaction listed in Table 1 is the same from 1994 to 2006 . One would expect the responses to this question to be even more closely linked to economic growth than life satisfaction, because the central feature of growth is a rapid increase of real incomes, and such an increase would presumably lead directly to greater satisfaction with one's financial situation. Hence, one might expect that countries with higher growth rates of GDP per capita would have greater increments in financial satisfaction.

In fact, there is no evidence that a greater increase in financial satisfaction accompanies more rapid economic growth. As in the analysis of the WVS data, the regression line fitted to the Latin American data indicates a nil relationship (Figure 6). The results from the Latinobarometer buttress those from the World Values Survey.

If there is any less developed country where one would expect a positive impact of economic growth on SWB it would be China, whose growth rate since 1990 has been the highest ever recorded (Heston, Summers, and Aten 2011). Household appliances such as refrigerators and washing machines - quite rare in 1990 - are now commonplace in urban areas (OECD 2010b, 21). Color television 
sets currently average over one per household. By 2008, almost one in ten urban households owned a car and China had become the world's leading automobile producer (OECD 2010a, 6, 10).

Yet, the combined evidence from six SWB surveys is that life satisfaction in China has not improved, and, if anything, may have declined somewhat (Easterlin et al 2012). Life satisfaction appears to have followed a U-shaped trajectory, bottoming out in the first part of this millennium, and the recovery since then has left SWB somewhat short of its initial level (Figure 7).

The six surveys in Figure 7 vary in their comprehensiveness. In general, they are more representative of urban areas, but, then, income growth was much higher in urban areas 5 . If economic growth has a strong positive effect on SWB, one would expect that in a two-decade period of more than fourfold real income growth per capita any sizable impact on SWB would be picked up in most of these surveys. Yet, all but one fail to give any indication of a marked increase of the type one would expect based on the cross section studies.

The one exception is the PEW survey. But in this survey the initial observation falls at an economic trough, and the subsequent increase captures the recovery segment of the $U$. This is evidenced by comparison with the other surveys in Figure 7. It is also apparent from data in the PEW survey itself. Among other things, respondents were asked, "Now thinking about our economic situation, how would you describe the current economic situation in China? Is it very good, somewhat good, somewhat bad, or very bad?" Here are the responses to this question, along with the survey values for mean life satisfaction in 2002 and 2010 : 


$\begin{array}{ccc}\underline{\text { Year }} & \begin{array}{c}\text { Economic situation (\% } \\ \text { somewhat or very good) }\end{array} & \begin{array}{c}\text { Mean life satisfaction } \\ \text { (scale 0-10) }\end{array} \\ 2002 & 52 & 5.27 \\ 2010 & 93 & 5.85\end{array}$

Clearly the increase in life satisfaction in China reported in the PEW surveys occurs in conjunction with a marked improvement in the economy.

Misreading the long term relationship - The PEW data illustrate a widely observed relationship, namely, that in the short term happiness goes up and down with the state of the economy ${ }^{6}$. Analysts who observe the short term relationship often confuse it with the long term one, which is nil. The Pew Research Center, in its commentary on the results of its surveys states: "The relationship between rising incomes and increasing happiness is most evident in China, India, Latin America, and Eastern Europe" (Pew Research Center, 2007, 1). Evidence that the increase in SWB reported for China after 2002 is the short term one has just been presented. Similar evidence for the movements in India and Latin America is found in other studies ${ }^{7}$. There was a serious worldwide setback to economic growth at the beginning of this millennium (United Nations, 2002, 2003). The upswings reported in the PEW surveys are probably representative of a phenomenon common to many countries throughout the world. (The time series movement in eastern Europe, mentioned in the PEW quotation above, is a somewhat different matter, as will be seen shortly.)

Another example of how shorter term movements are mistaken for the longer term relationship of happiness and economic growth appears in a recently published article by Sacks, Stevenson, and Wolfers (S-S-W, 2012). In the analysis 
above of 17 developed countries, Ireland has the highest growth rate of GDP per capita, but only an average rate of change in SWB (Figure 2). In analyzing the same Eurobarometer data, S-S-W inexplicably replace the long term change by shorter decade-to-decade movements (pp. 82-84). Figure 8 reproduces Figure 2 with the single observation in Figure 2 for Ireland now replaced by three sub-period observations.

As can be seen, the result, not surprisingly, is to tilt the regression relationship in a positive direction. The earliest S-S-W observation, that labeled 7887, spans a period in which the economy plunged into a major recession - the economic growth rate is among the lowest and the rate of change in SWB is negative. The subsequent recovery (88-98) yields an observation of high economic growth coupled with a positive increment in life satisfaction, and the two points together make for a positively-sloped regression line. However, even after replacing the long term change with shorter term changes for a number of Eurobarometer countries in addition to Ireland, S-S-W are only able to conclude (p. 84) that the "estimated satisfaction-income gradient resulting from these long-run differences is marginally statistically significant at 0.28 " (emphasis added). Although shorter periods tend to obscure the long term relationship, apparently in this case the subperiod changes used by S-S-W weren't quite enough to turn a nil relationship into a significantly positive one by accepted standards.

A somewhat different reason for misreading the SWB-GDP relationship occurs in regard to the transition countries of eastern Europe. In this case the problem is that there are no pre-transition SWB data for a number of countries and 
the first happiness observation in such countries occurs after the transition is already underway. This can be illustrated by the data for Slovenia. The earliest SWB observation there occurs in 1992, and if one simply examines the trend in SWB and GDP from 1992 onward, one finds a positive change in both (Figure 9). If, however, one considers the course of GDP prior to 1992, in the period before SWB data became available, one finds a sharp decline. The collapse and recovery of GDP observed in Slovenia is typical of most transition countries. In those for which there is also a SWB observation prior to the collapse, one finds life satisfaction moving down with GDP, and then turning upward along with the economy (Figure 10). Aside from the German Democratic Republic (GDR), the timing of the SWB and GDP movements in Figure 10 are not completely synchronous because the SWB observations are intermittent, rather than annual as for GDP. In the countries other than Slovenia in Figure 10, the first SWB observation occurs when the economy was at or near full employment and close to its previous GDP maximum (Table 2). As is clear from the table, in Slovenia the first SWB observation occurs when there is already substantial unemployment and GDP is well below its prior peak. The SWB data for a number of transition countries are like that for Slovenia, with the first observation falling at a date when the transition is already well underway. As a result, analysts of SWB and GDP in transition countries tend to take the recovery of SWB and GDP as indicative of the longer term change and of a positive long run SWB-GDP relationship ${ }^{8}$. However, as seen in Figure 4 above, for the transition countries for which there is a pre-transition SWB observation, the long term relationship is, in fact, nil. 
The question posed at the start of the section was whether economic growth in itself leads to increased happiness. The answer suggested by the evidence surveyed - 17 developed countries, 9 developing countries, 11 transition countries, 17 Latin American countries, and China - is, no. Contrary conclusions are due to analysts confusing the short-term (positive) relation of SWB and GDP with the longterm (nil) relation, or drawing inferences from transition countries like Slovenia that lack a pre-transition SWB observation.

\section{PUBLIC POLICY AND HAPPINESS}

If economic growth in itself does not increase happiness, are there other policies that will? The answer is, yes, full employment and safety net polices increase happiness.

There is extensive evidence in the happiness literature that unemployment has a significant and sizable negative impact on $\mathrm{SWB}^{9}$. DiTella, MacCulloch, and Oswald (2001) report that this effect is felt by employed as well as unemployed persons. The policy implication is straightforward - full employment policies will increase happiness.

The positive effect of safety net policies on happiness is suggested in another study by DiTella, MacCulloch, and Oswald $(2003,821)$, who in a multivariate analysis find that "the [OECD unemployment] benefit rate is positively associated with happiness levels and is well-defined statistically." The political science 
literature on SWB provides additional support for the positive impact on SWB of safety net policies ${ }^{10}$.

In what follows, I present additional evidence on the positive relation between happiness, on the one hand, and full employment and safety net policies, on the other. First, I compare European countries with the same GDP per capita, but different socio-economic policies, to see whether there is any difference in happiness. Second, I examine the course of happiness in China and a European transition country (the former GDR) in the period when employment and safety net policies were effectively abandoned.

European welfare states - For simplicity, Denmark, Sweden, and Finland are grouped together here as "ultra-welfare states," and France, Germany, Austria, and the United Kingdom, as "semi-welfare states." Macro-economic conditions - GDP per capita, and inflation and unemployment rates - in the two groups are virtually the same (Table 3).

Public policies in the ultra-welfare states, however, are more generous and comprehensive than in the semi-welfare states. To demonstrate the policy differences I use the benefit generosity indexes created by political scientist Lyle Scruggs $(2004,2006)$ who, in turn, built on the earlier work of Esping-Andersen (1990). Scruggs' indexes take account of income replacement rates and the scope and duration of benefit coverage. Data for the most recent year available in the Scruggs estimates, 2002, are used here. I also use responses to several questions in the 2007 European Quality of Life Survey on people's subjective feelings and attitudes. 
As a preliminary check on Scruggs' measures, it is possible to compare the OECD's summary measure of the average income replacement rate due to unemployment benefits with the Scruggs generosity index for unemployment benefits (Table 4). As can be seen, the ultra-welfare states are considerably more generous on both the OECD and Scruggs measures, suggesting that Scruggs' generosity index is consistent with the OECD measure.

Scruggs' estimates indicate differences between the ultra-welfare states and semi-welfare states in the generosity of sickness and pension benefits much like the difference in unemployment benefits (Table 5). Scruggs' overall benefit measure is obtained by adding these three generosity indexes. Summarizing the evidence in the table, the policies of the ultra-welfare states are uniformly more generous than those of the semi-welfare sates.

The differences in public policies between the two sets of countries are reflected in peoples' satisfaction with their lives. Respondents in the ultra-welfare states are, on average, more satisfied with their work, health, and family life than in the semi-welfare states, and they also report greater overall life satisfaction (Table 6).

The correspondence between the satisfaction and public policy differences for the two sets of countries is consistent with the findings in the SWB literature that there is a causal connection running from full employment and safety net policies to happiness. But, as a check, I consider whether people give any evidence that they are aware of and responsive to these policy differences. One indication is provided by respondents' ratings of public services. On average, those in ultra- 
welfare states give consistently higher ratings of a wide range of public services: health, education, care of children and the elderly, and public pensions (Table 7). They also consistently express greater trust in the political system (Table 8). It seems that, in general, people are aware of and responsive to more generous social policies and, because of these policies, are more satisfied with their lives. Although the ultra-and semi-welfare states have quite similar economic conditions, happiness is higher in the set of countries where socio-economic policies are more generous and comprehensive.

Transition countries - The second piece of new evidence that happiness is positively related to full employment and safety net policies comes from the experience of the transition countries. In this case, there has been a substantial retreat from these policies. Hence one would expect a negative impact on happiness.

Prior to the transition, the typical situation in these countries was one of full employment and a comprehensive social safety net. Here is a description of workers' conditions pre-transition in three different countries by three different analysts.

\section{China}

Job rights have until very recently been firmly entrenched in urban China ..... Stateowned enterprises have ...supplied extensive welfare benefits, including housing, medical services, pensions, childcare, and jobs for [grown] children ... Almost all state employees, and many in the larger collectives, have thus enjoyed an 'iron rice bowl' ... lifetime tenure of their job and a relatively high wage in the enterprise representing a 'mini welfare state' (Knight and Song, 2005, 16-17). 


\section{East Germany}

Over the 40 years of its existence, the DDR had developed as a completely different state from the BDR. There was no unemployment, no (open) inflation, low work intensity, free medical services, low prices for housing and public transport (Lumley $1995,29)$.

$\underline{\text { Russia }}$

Before 1989, Russians lived in a country that provided economic security: unemployment was virtually unknown, pensions were guaranteed and provided a standard of living perceived to be adequate, and macroeconomic instability did not much effect the average citizen (Brainerd and Cutler 2005, 125).

The similarity among these descriptions is striking - clearly full employment and a comprehensive safety net was the norm prior to the transition.

The transition brought an end to full employment and the social safety net. Unemployment rates rose from near-zero to two-digit levels (Figure 11). Safety net benefits, which were typically provided through state-owned enterprises, disappeared as workers lost jobs and/or shifted to private firms. The severity in China of the effects of this "re-structuring" of the economy are suggested by the following two quotations from a World Bank document:

By all measures, S.O.E. restructuring had a profound effect on the functioning of the labor market and the welfare of millions of urban workers. Most urban centers experienced a sharp rise in unemployment and a large reduction in labor force participation as many older and discouraged workers left the labor force (World Bank, 2007, 19).

S.O.E. restructuring ... mark[ed] the end of the 'iron rice bowl' of guaranteed lifetime employment and benefits for urban workers (World Bank, 2007, 17). 
As has been seen, life satisfaction in China over the last two decades remained constant or perhaps even declined, despite a more than fourfold multiplication of output and incomes. It seems reasonable to infer that with the emergence and rise of unemployment, and breakdown of the social safety net, new concerns arose among workers about such things as jobs and income security, the availability of health care and pensions, and provision for care of children and the elderly. Rapid economic growth may have alleviated these concerns by providing increased employment opportunities, but the net effect was no gain in happiness.

The survey data for East Germany, the former German Democratic Republic, provide specific evidence of the emergence of job and safety net concerns. These surveys ask about satisfaction, not only with life in general, but also about satisfaction with various aspects or "domains" of life, data not available for China.

Between June 1990 (just prior to the transition) and 2004, East Germans' satisfaction increased with a number of material aspects of life (Table 9). The marked increase in satisfaction with the environment and availability of goods is noteworthy. These are two features of life in the GDR that were often spoken of disparagingly by contemporary observers. All of the other material dimensions of life in Table 9 also show at least modest improvement.

Counterbalancing these improvements, however, are sizable negative changes in satisfaction with health, work, and childcare (Table 9). Prior to the transition, people were assured of jobs and substantial social support. With the retreat from full employment and a social safety net, concerns regarding these important aspects of life mounted, and satisfaction correspondingly declined. The 
outcome, as in the case of China, was a negative impact on happiness, and no improvement in overall life satisfaction.

The general conclusion from this section is that full employment and safety net policies increase happiness. This is suggested, first, by prior studies in the happiness literature. It is seen here in evidence from European welfare states, where, controlling for GDP per capita, those with more generous and comprehensive socio-economic policies are happier. Finally, it is evidenced in the experience of two transition countries examined here, China and the former GDR. Despite a marked difference in their output trajectories, the two countries exhibit a similar life satisfaction pattern of no long term improvement, resulting from a common retreat from full employment and a comprehensive safety net.

\section{AFFORDABILITY}

Incomes are low in many countries throughout the world and promoting economic growth is, in consequence, often viewed as a high policy priority. As has been seen, however, if the goal is to increase happiness, economic growth in itself is unlikely to do the job. Full employment and social support policies will increase happiness, but such policies are often seen as a luxury of higher income nations. Hence, it is essential to ask whether social insurance of the type discussed above is affordable in today's less developed world.

To answer this, let us go back to the origins of social insurance, as identified by historians, in late nineteenth century Germany. Legislation there in 1883 
initiated sickness insurance; in 1884, industrial accident insurance; and, in 1889, public pensions.

In the 1880s, Germany's real GDP per capita in 2005 dollars was about $\$ 3200$ (Heston, Summers, and Aten 2011). How do the incomes of today's less developed countries (LDCs) compare with that of Germany in the 1880s? If we take population size into account, about three-fourths of the population of the less developed world lives in countries whose GDP per capita exceeds $\$ 3200$, and 43 per cent live in countries whose level is $\$ 6400$ or more, at least double that of Germany in the 1880s (Heston, Summers, and Aten 2011). Most of those living in countries below $\$ 3200$ are in Sub-Saharan Africa.

Turning from levels of GDP per capita to rates of change, how do growth rates in today's LDCs compare with the per annum 1.8 per cent growth rate of Germany in the 1880s? The answer is that, on average, today's LDC growth rate is almost three times that of Germany's (Table 10). If China and India, large countries with considerably above average growth rates, are excluded, the average growth rates of GDP per capita in LDCs in the major areas of the world are still considerably above the German growth rate of the 1880s, and this includes Sub-Saharan Africa.

In sum, countries accounting for three-fourths of the world's population have both a higher level and higher growth rate of GDP per capita than Germany in the 1880s, when it initiated social insurance programs. By this measure, social insurance is affordable in most LDCs. Indeed, a number of LDCs are starting to implement various types of social insurance, sometimes with the help of 
international organizations ${ }^{11}$. These programs are typically less than comprehensive, but the same was true of Germany's initial programs.

\section{SUMMARY AND IMPLICATIONS}

The answers to the three questions posed in the Introduction can be briefly summarized:

1. Economic growth in itself does not raise happiness. Evidence for a wide range of developed, transition, and developing countries consistently shows that higher growth rates are not accompanied by greater increments in happiness. Even China, with the highest rate of economic growth ever recorded, has no improvement in life satisfaction. Analysts claiming that growth and happiness go together are mistaking the short term positive relation for the long term nil relation, or, in the case of the transition countries, starting from a date after the economy has already collapsed in the course of transition. The time series data make clear that cross section studies are a misleading basis for drawing conclusions about historical experience.

2. Full employment and safety net policies do increase happiness. The evidence for this is, first, prior work in the happiness literature. Second, when one compares European countries with the same macro-economic conditions but different welfare policies, one finds that the set of countries with more generous welfare policies are happier. Finally, in the transition 
countries the abandonment of full employment and safety net policies had a negative impact on happiness.

3. Employment and safety net policies are affordable in most countries throughout the world. Among less developed countries, those accounting for three-quarters of LDC population have both a higher level and higher growth rate of GDP per capita than Germany in the 1880s, when it pioneered social insurance programs.

These conclusions do not necessarily mean that economic growth should be abandoned as a policy goal. In principle, economic growth should contribute to greater employment and make safety net policies easier to implement, though this has not been demonstrated here. Clearly there is much more research to be done, but it is evident that the sole promotion of economic growth as a cure-all is not a valid policy solution to raising happiness.

It is important too to note that the present analysis demonstrates the value of subjective well-being measures like happiness and life satisfaction as guides to policy. Output measures lead one to focus on firms and their productivity, while happiness measures lead directly to the lives and personal concerns of individuals. Moreover, happiness and life satisfaction are concepts with which a layman can identify, unlike GDP. Both GDP and subjective well-being have their uses, but policymaker's preoccupation with GDP has too often led to neglect of the individuals whose welfare is or should be the primary object of policy. 


\section{References}

Aspalter, C. "Pension Coverage and Demographic Aging." International Social Security Association, Regional Social Security Forum for Asia and the Pacific, Manila, Philippines, 2009.

Blanchflower D.G., A.J. Oswald. "Well-being over time in Britain and the USA." Journal of Public Economics, 88, 2004, 1359-1386.

Brainerd, E., D.M. Cutler. "Autopsy on an Empire: Understanding Mortality in Russia and the Former Soviet Union." Journal of Economic Perspectives, 19(1), 2005, 10730 .

Chinese Academy of Social Sciences. Blue Book of China's Society: Society of China Analysis and Forecast (in Chinese). China: Social Sciences Academic Press, 2011.

Clark A., Y. Georgellis, P. Sanfey. "Scarring: The Psychological Impact of Past Unemployment.” Economica, 68, 2001, 221-241.

Deaton, A. "Income, Health, and Well-Being around the World: Evidence from the Gallup World Poll." Journal of Economic Perspectives, 22(2), 2008, 53-72.

DiTella R., R.J. MacCulloch, A.J. Oswald. "Preferences over Inflation and Unemployment: Evidence from Surveys of Happiness." American Economic Review, 91(1), March 2001, 335-241.

DiTella R., R.J. MacCulloch, A.J. Oswald. "The Macro-Economics of Happiness.” Review of Economics and Statistics, 85(4), 2003, 809-827.

Easterlin R.A. Happiness, growth, and the life cycle. New York: Oxford University Press, 2010.

Easterlin R.A., L.V. McVey, M. Switek, O. Sawangfa, J.S. Zweig. “The Happiness-Income Paradox Revisited." Proceedings of the National Academy of Sciences, 107(52), 2010, 22463-22468.

Easterlin R.A., O. Sawangfa in International Differences in Well-Being, edited by E. Diener, J.F. Helliwell, D. Kahneman. New York: Oxford University Press, 2010, 166216.

Easterlin R.A., R. Morgan, M. Switek, F. Wang. "China's life satisfaction, 1990-2010.” Proceedings of the National Academy of Sciences, 2012, available at: http://www.pnas.org/content/early/2012/05/09/1205672109.abstract 
Economic Commission for Europe. Economic Survey of Europe, No. 1. New York and Geneva: United Nations, 2003.

Esping-Andersen, G. The Three Worlds of Welfare Capitalism. Princeton, NJ: Princeton University Press, 1990.

European Foundation. European Quality of Life Survey 2007. Available at: http://www.eurofound.europa.eu/areas/qualityoflife/eqls/2007/index.htm, 2007.

Federal Statistical Office of Germany. Online DatenBank. Available at: https://wwwgenesis.destatis.de/genesis/online/data

Flavin, P., A.C. Pacek, B. Radcliff. "State Intervention and Subjective Well-Being in Advanced Industrial Democracies." Politics and Policy, 39(2), 2011, 251-269.

Frey B.S., A. Stutzer Happiness and Economics: How the Economy and Institutions Affect Well-Bing. Princeton: Princeton University Press, 2002.

Fuchs V. How we live. Cambridge: Harvard University Press, 1983.

Guriev S., E. Zhuravskaya “(Un)happiness in Transition." 2008. Available at: http://papers.ssrn.com/sol3/papers.cfm?abstract_id=1077709

Haisken-DeNew J.P., Frick J.R. Desktop Companion to the German Socieo-Economic Panel (SOEP), Version 8.0 DIW. Berlin: German Institute for Economic Research, 2005.

Helliwell, J., R. Layard, J. Sachs. World Happiness Report. New York: United Nations, 2012.

Heston, A., R. Summers, B. Aten, Penn World Table Version 7.0, Center for International Comparisons of Production, Income and Prices at the University of Pennsylvania, May 2011.

Holzmann, R. "Global Pension Systems and Their Reform: Worldwide Drivers, Trends, and Challenges." Social Protection and Labor Discussion Paper Series No. 1213. Washington D.C.: World Bank, 2012.

ILO, Labor Statistics Database, available at: http://laborsta.ilo.org

Inglehart R.F. "Globalization and postmodern values." The Washington Quarterly, 23(1), 2002, 215-228.

Kassenboehmer S.C., J.P. Haisken-DeNew. "You're Fired! The Causal Negative Effect of Entry Unemployment on Life Satisfaction." The Economic Journal, 119, 2009, 448462. 
Knight J, L. Song. 2005 Towards a Labour Market in China. New York: Oxford University Press, 2005.

Knight J, J.J. Xue. "How High is Urban Unemployment in China?” Journal of Chinese Economic and Business Studies, 4(2), 2006, 91-107.

Kudo, A. "Public Employment Services and Activation Policies." Social Protection and Labor Discussion Paper Series No. 1215. Washington D.C.: World Bank, 2012.

Lumley R. "Labour Markets and Employment Relations in Transition in Countries of Central and Eastern Europe.” Employee Relations, 17, 1995, 24-37.

McCloskey D.M. “The Rhetoric of Economics.” Journal of Economic Literature, 21(2), 1983, 481-517.

OECD, China in the 2010s: Rebalancing Growth and Strengthening Social Safety Nets. Beijing: OECD, 2010a.

OECD, OECD Economic Surveys: China, Vol. 2010/6. Beijing: OECD, 2010 b.

PEW Research Center. Global Attitudes Project (Summer 2002, May 2005, Spring 2007, and Spring 2010 surveys), 2011. Available at:

http://www.pewglobal.org/category/datasets/. Downloaded on October 17, 2011.

Rofman, R. “Social Security Coverage in Latin America.” Social Protection Discussion Paper Series No. 0253. Washington, D.C., World Bank Social Protection Unit, 2005.

Sacks, D.W., B. Stevenson, J. Wolfers. "Subjective Well-Being, Income, Economic Development, and Growth" in ... and the Pursuit of Happiness: Well-Being and the Role of Government, edited by P. Booth. London: the Institute of Economic Affairs, 2012.

Sanfey P., L.J. Teksoz. “Transition Make You Happy?” Economics of Transition, 15, 2007, 707-731.

Scruggs, L. Welfare State Entitlement Data Set: A Comparative Institutional Analysis of 18 Welfare States, Version 1.1 (June 1, 2005), 2004.

Scruggs, L. “The Generosity of Social Insurance, 1971-2002." Oxford Review of Economic Policy 22(3), 2006, 349-364.

Stevenson B., Wolfers J. "Economic Growth and Subjective Well-Being: Reassessing the Easterlin Paradox." Brookings Papers on Economic Activity, spring 2008, 1-87. 
Stiglitz, J.E., A. Sen, J.P. Fitoussi. Report of the Commission on the Measurement of Economic Performance and Social Progress, 2008. Available at: www.stiglitz-senfitoussi.fr

Tzannatos, Z. S. Roddis. "Unemployment Benefits." Social Protection and Labor Discussion Paper Series No. 9813. Washington D.C.: World Bank, 1998.

United Nations. World Economic Situation and Prospects 2002. New York: United Nations, 2002.

United Nations. World Economic Situation and Prospects 2003. New York: United Nations, 2003.

Veenhoven R. “Is happiness relative?" Social Indicators Research, 24, 1991, 1-34.

Vodopivec M., M.H. Tong. China: improving unemployment insurance. Washington D.C.: World Bank, 2008.

World Bank. China's Modernizing Labor Market: Trends and Emerging Challenges. Washington D.C.: World Bank, 2007.

World Bank. World Development Indicators. Washington D.C.: World Bank, available at: http://data.worldbank.org/data-catalog/world-development-indicators

Winkelmann L, R. Winkelmann. "Why Are the Unemployed So Unhappy? Evidence from Panel Data." Economica, 65, 1998, 1-15.

Xu C.G. "The Fundamental Institutions of China's Reforms and Development." Journal of Economic Literature, 49(4), 2011, 1076-1151. 
Abbreviations:

SWB: Subjective well-being

GDP: Gross domestic product

LDCs: Less developed countries

WVS: World Values Survey

S-S-W: Sacks, Stevenson, and Wolfers

GDR: German Democratic Republic 
TABLE 1

Measures of Subjective Well-Being

1. Happiness (United States General Social Survey): “Taken all together, how would you say things are these days, would you say that you are very happy, pretty happy, or not too happy?" (Coded 3,2,1).

2. Life Satisfaction (World Values Survey): "All things considered, how satisfied are you with your life as a whole these days? Please use this card to help with your answer."

1 'Dissatisfied' 234578910 'Satisfied'

3. Financial Satisfaction (Latinobarometer): "How would you define, in general, the current economic situation of yourself and your family?

Would you say that it is.....

1= Very bad; 2=Bad; 3=Regular; 4=Good; 5=Very Good" 
TABLE 2

GDP Index and Unemployment Rate at Date of Earliest Life Satisfaction (LS) Observation

$\begin{array}{lccc}\text { Former GDR } & \begin{array}{c}\text { Date of Earliest LS } \\ \text { Observation }\end{array} & \begin{array}{c}\text { GDP index } \\ (1989=100)\end{array} & \begin{array}{c}\text { Unemployment } \\ \text { Rate, per cent }\end{array} \\ \text { Estonia } & 1989.5 & 92 & 0 \\ \text { Latvia } & 1989.5 & 96 & 1.6 \\ \text { Lithuania } & 1989.5 & 101 & 2.3 \\ \text { Belarus } & 1989.5 & 98 & 3.5 \\ \text { Russian Fed. } & 1990 & 98 & 0.5 \\ \text { Slovenia } & 1990 & 97 & 0.1 \\ & 1992 & 84 & 10.1\end{array}$

Source: Economic Commission for Europe 2003, Table B-1, B-5. 
TABLE 3

Macro-Economic Indicators, Average for Two Sets of European Welfare States, 2007

$$
\text { GDP per capita }
$$

$(\$ 000)$

34.3

33.4
Inflation rate

$(\% / y r)$

2.1

2.1
Unemployment rate

5.6

6.6

Ultra-Welfare States: Denmark, Finland, and Sweden.

Semi-Welfare States: France, Germany, Austria, and UK.

Source: GDP, available at: http://databank.worldbank.org, accessed December 2009; Unemployment rate, OECD Labour Force Statistics (MEI), available at: http://stats.oecd.org/Index.aspx?datasetcode=meilabour, accessed June 2011, and International Labour Organization, Labour Statistics Database, available at: http://laborsta.ilo.org, accessed on July 2011; Inflation rate, OECD Statistical Database, available at: http://stats.oecd.org, accessed on July 2011. 
TABLE 4

Measures of Unemployment Benefits, OECD and Scruggs, Average for Two Sets of European Welfare States

\author{
OECD \\ Income Replacement \\ Rate, 2007
}

Ultra-Welfare States

Semi-Welfare States
$(\%)$

38.0

27.4
Scruggs

Generosity Index Unemployment Benefits, 2002

(scale, 0-15)

9.9

6.6

Source: OECD gross replacement rate (GRR), see OECD online datasets, available at: http://www.oecd.org/dataoecd/60/8/49971171.xlsx, Scruggs (2004). 
TABLE 5

Benefit Generosity of Various Public Policies, Average for Two Sets of Welfare States, 2002

a-Welfare States

Unemployment

Benefits

$(0-15)$

9.9

6.6

Scruggs Generosity Index

Semi-Welfare States

$\begin{array}{cc}\text { Sickness } & \text { Pension } \\ \text { Benefits } & \text { Benefits } \\ (0-15) & (0-17) \\ 11.4 & 12.5 \\ 9.2 & 10.4\end{array}$

Overall

Benefits

$(0-47)$

33.8

26.2

Source: Scruggs (2004). 
TABLE 6

Satisfaction with Work, Health, Family Life, and Life in General, Average for Two Sets of European Welfare States, 2007

(Could you please tell me on a scale of 1 to 10 how satisfied you are with each of the following items, where 1 means very dissatisfied and 10 means very satisfied? Your

Life in

Ultra-Welfare States

Work

8.0

Health

Semi-Welfare States

7.2

7.9

7.4

Family Life

8.6

8.0

General

8.4

7.2

Source: European Foundation, European Quality of Life Survey 2007. 


\section{TABLE 7}

Respondents' Ratings of Government Services, Average for Two Sets of European Welfare Countries, 2007

(In general, how would you rate the quality of each of the following PUBLIC services? 1-10 scale)

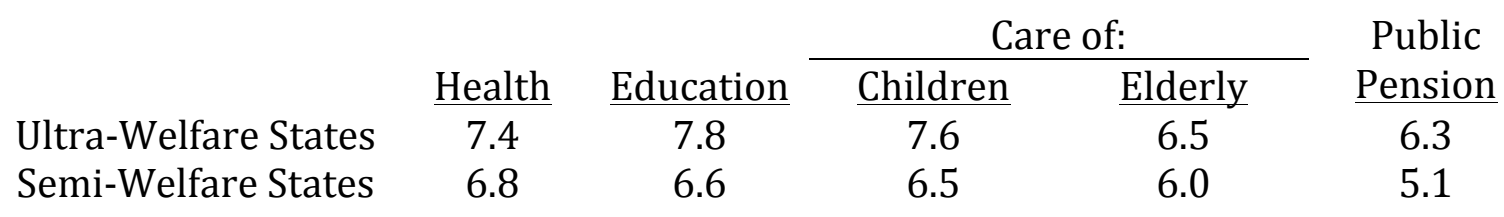

Source: European Foundation, European Quality of Life Survey 2007. 


\section{TABLE 8}

Respondents' Ratings of Trust in Political System, Average for Two Sets of European Welfare Countries, 2007

(Please tell me how much you trust each of the following institutions...1=do not trust at all, 10=trust completely)

\begin{tabular}{|c|c|c|c|}
\hline & Government & Political Parties & Legal System \\
\hline Ultra-Welfare States & 6.3 & 5.7 & 7.4 \\
\hline Semi-Welfare States & 5.0 & 4.2 & 5.8 \\
\hline
\end{tabular}

Source: European Foundation, European Quality of Life Survey 2007. 
TABLE 9

Satisfaction with Various Life Domains, East Germany, 1990 and 2004 (scale $0-10$ )

$\begin{array}{llll}\text { Domain } & \underline{1990} & \underline{2004} & \underline{2004} \\ \text { Positive Changes: } & & & \\ \quad \text { Environment } & 3.11 & 6.47 & +3.36 \\ \quad \text { Goods availability } & 3.16 & 6.20 & +3.04 \\ \text { Dwelling } & 6.93 & 7.36 & +0.43 \\ \quad \text { Standard of living } & 6.34 & 6.63 & +0.29 \\ \quad \text { Household income } & 5.52 & 5.61 & +0.09 \\ \text { Negative changes: } & & & \\ \quad \text { Health } & 6.62 & 6.20 & -0.42 \\ \quad \text { Work } & 7.23 & 6.48 & -0.75 \\ \quad \text { Childcare } & 7.54 & 6.48 & -1.06 \\ \text { Overall life satisfaction } & 6.57 & 6.55 & -0.02 \\ & & & \\ \text { Source: GSOEP (Haisken-DeNew and Frick 2005). } & & \end{array}$


TABLE 10

Growth Rate of Real GDP per Capita, Germany, 1880s, and Less Developed Countries, 2000-2008

(per cent per year)

$\begin{array}{llll}\text { Germany } & 1.8 & \text { East Asia, except China } & 4.8 \\ & & \text { South Asia, except India } & 3.8 \\ \text { All LDCs } & 5.1 & \text { Middle East and North Africa } & 3.0 \\ \text { China } & 9.7 & \text { Latin America } & 2.7 \\ \text { India } & 6.4 & \text { Sub-Saharan Africa } & 2.7\end{array}$

Source: Heston, Summers, and Aten 2011. 
FIGURE 1

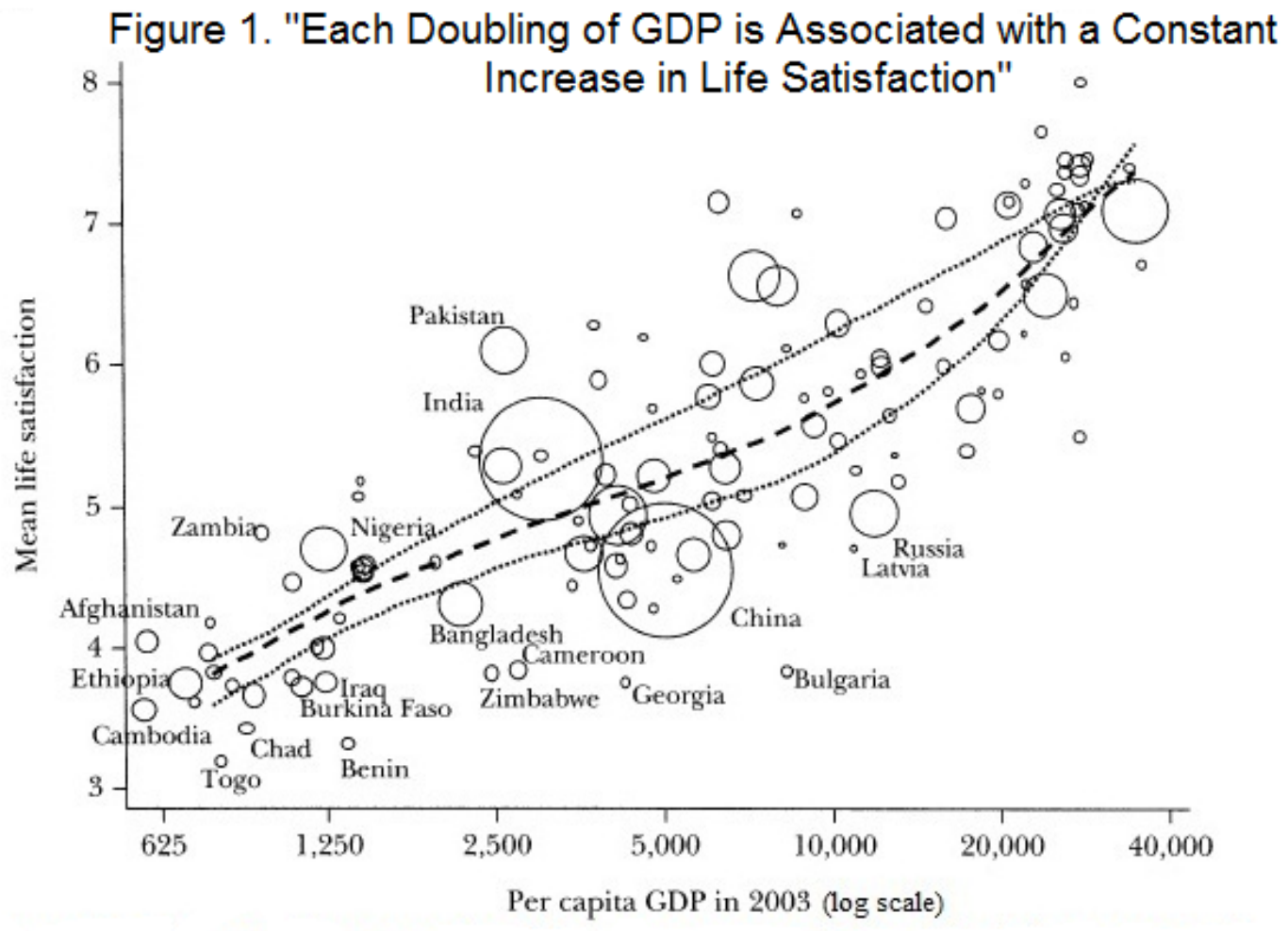


FIGURE 2

Figure 2. Growth Rate of Life Satisfaction and Real GDP

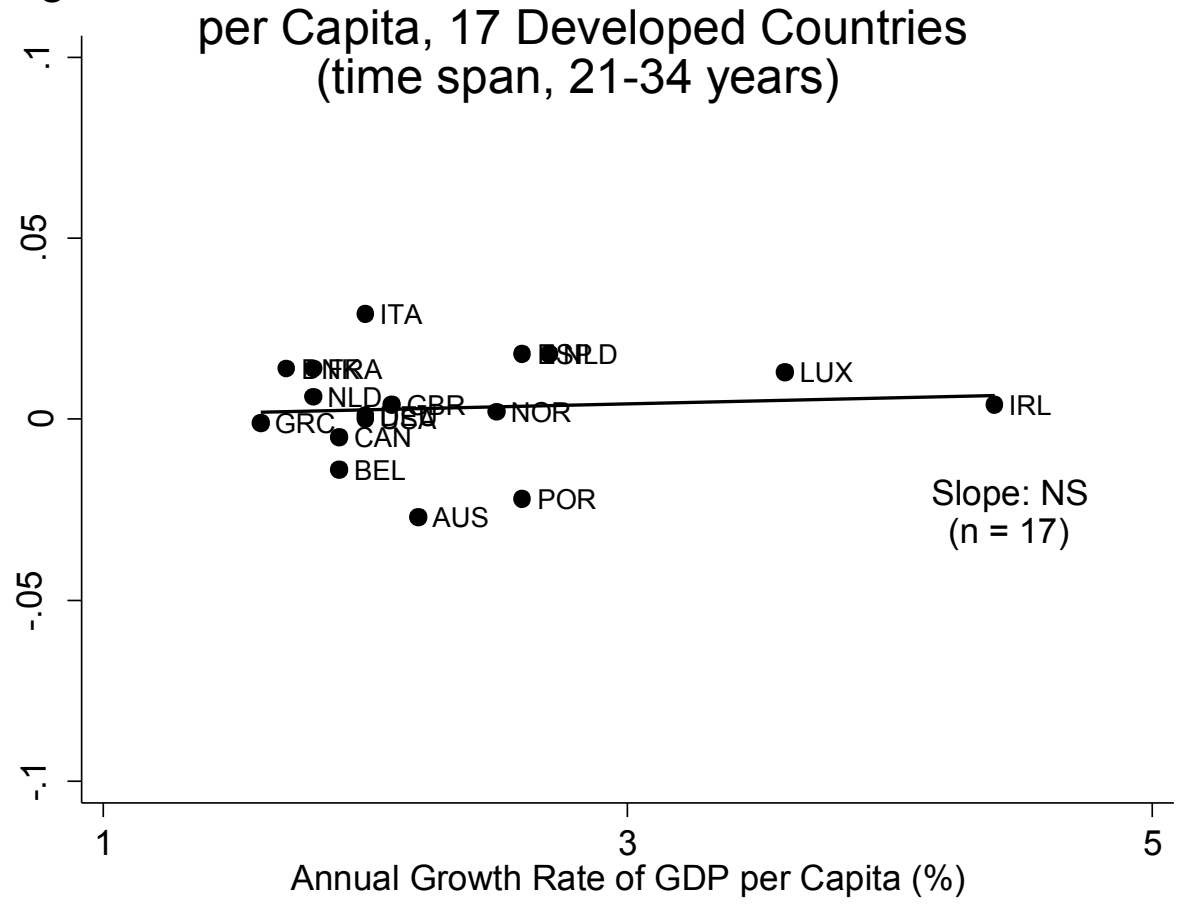


FIGURE 3

Figure 3. Growth Rate of Life Satisfaction and Real GDP r. $\quad$ per Capita, 9 Developing Countries

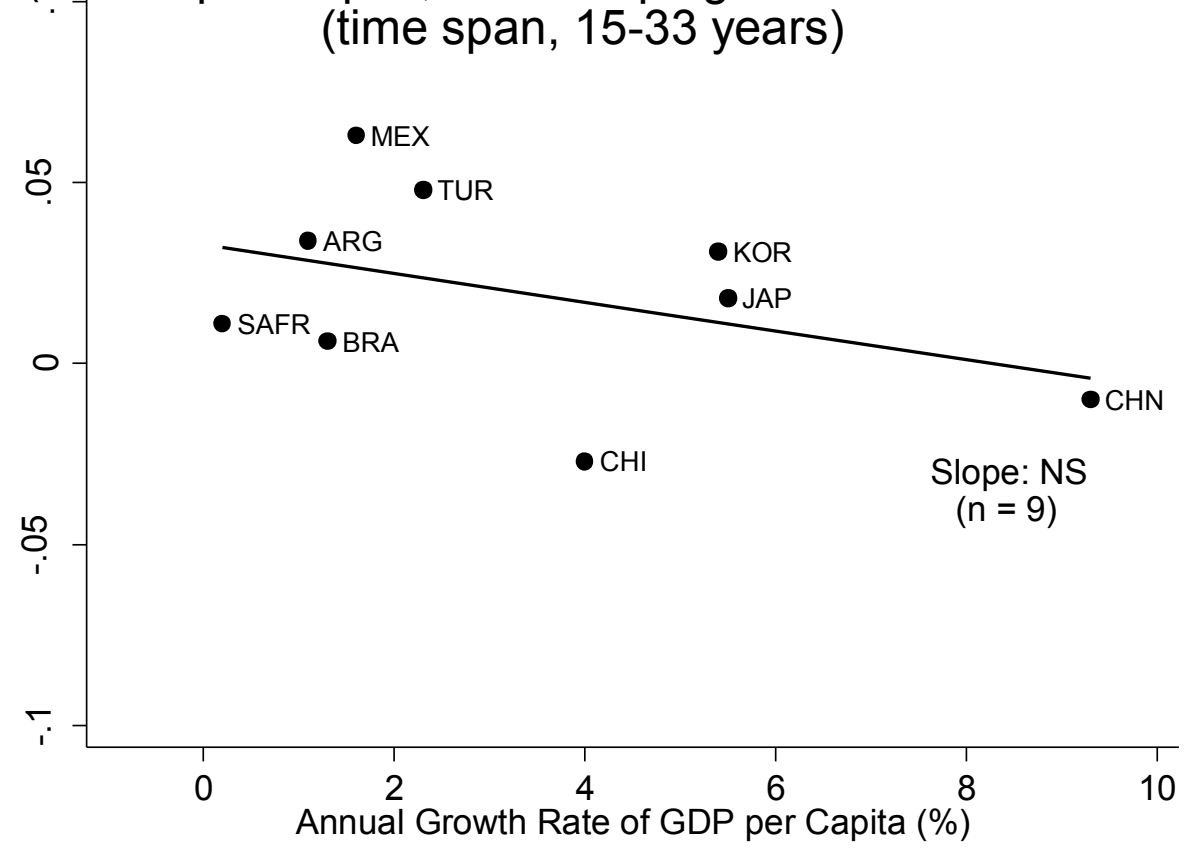


FIGURE 4

Figure 4. Growth Rate of Life Satisfaction and Real GDP

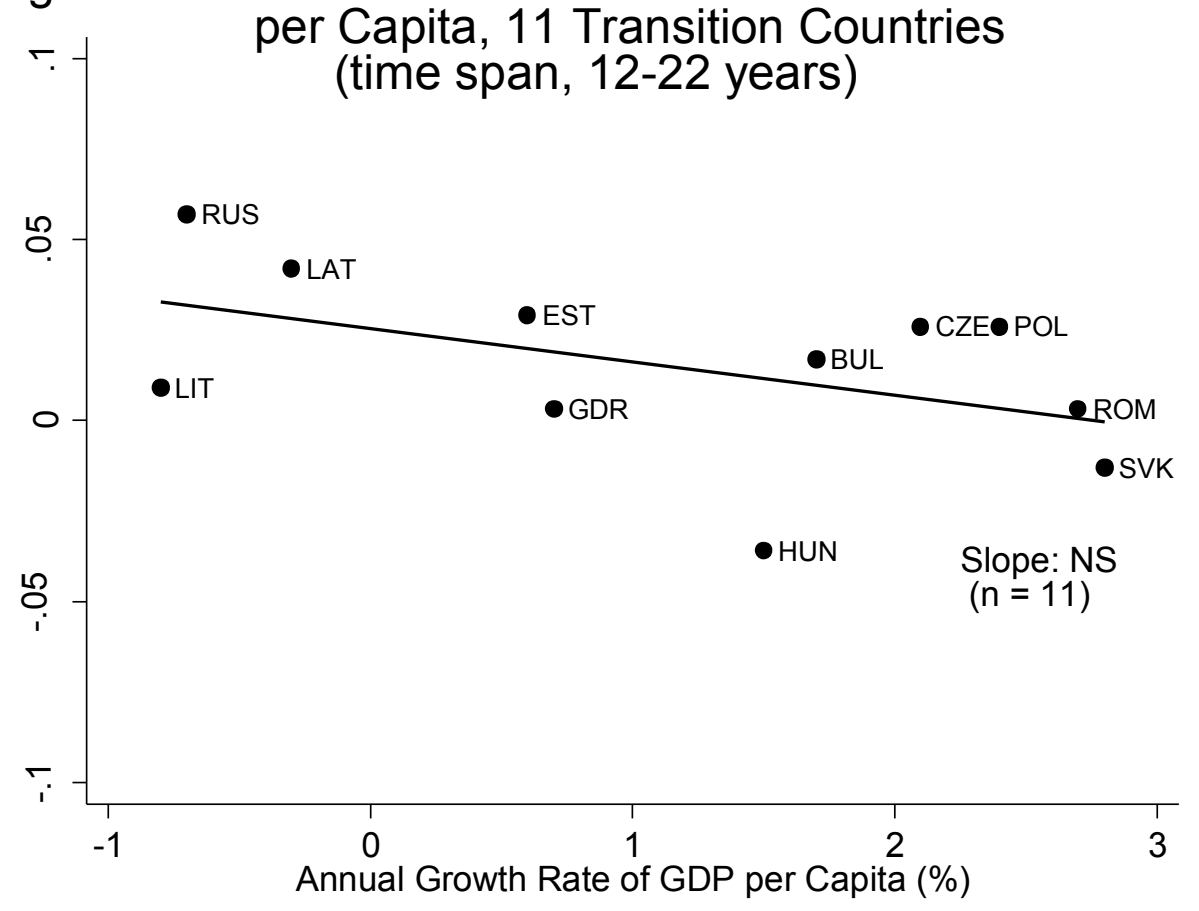


FIGURE 5

Figure 5. Growth Rate of Life Satisfaction and Real GDP _ per Capita, 17 Developed, 11 Transition, and 9

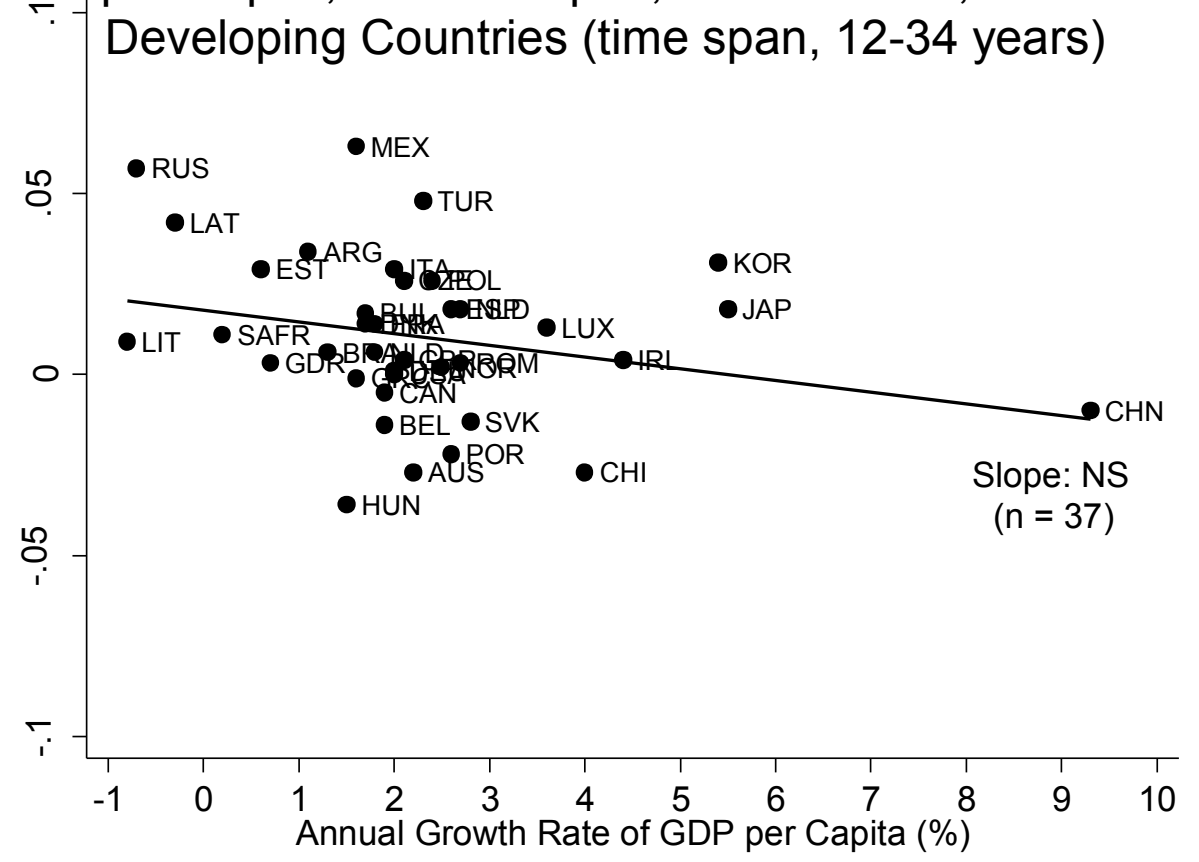


FIGURE 6

Figure 6. Growth Rate of Financial Satisfaction and Real

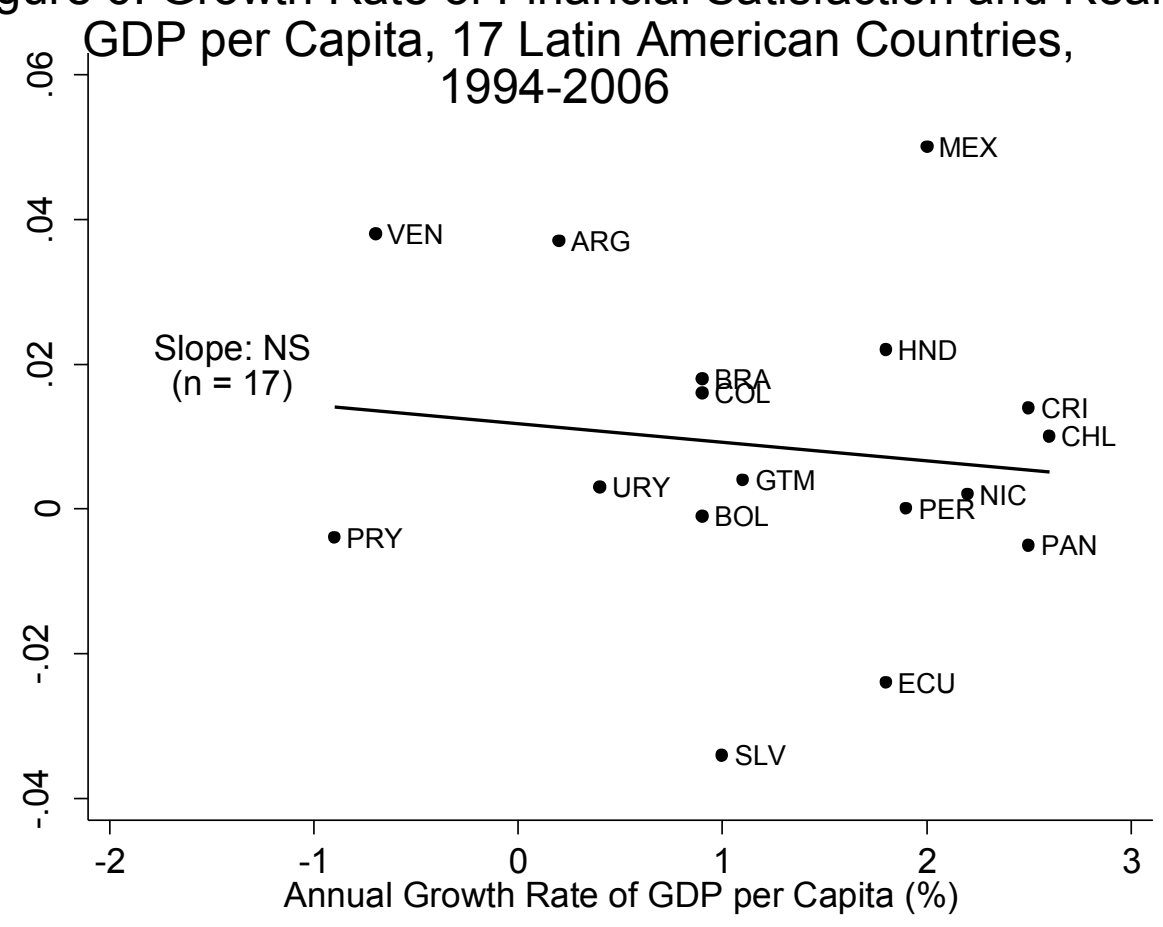


FIGURE 7

Figure 7. Mean Life Satisfaction, China, Six Series,

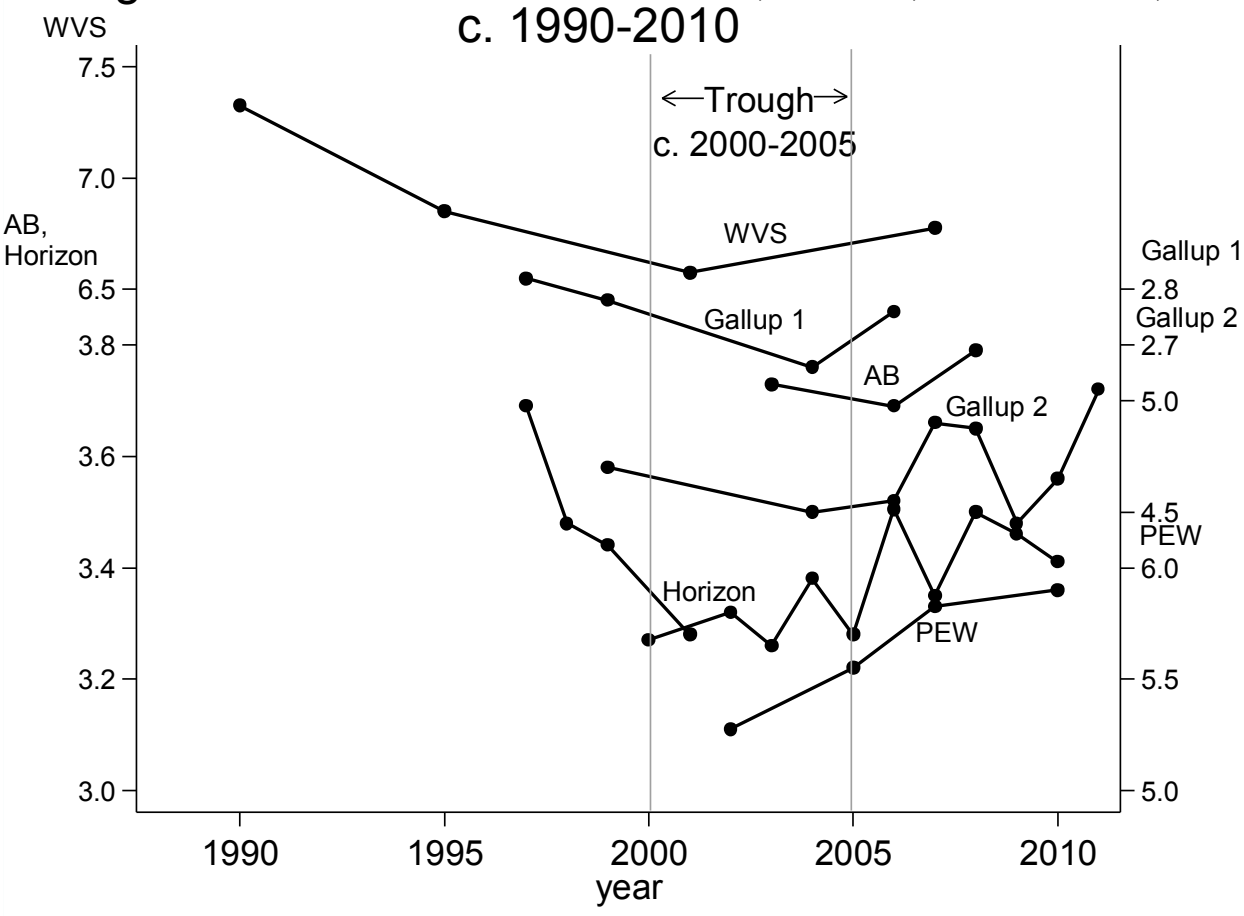


FIGURE 8

Figure 8. Figure 2 with Single Value for Ireland, 1973-2007, Replaced by Three Sub-Period Values

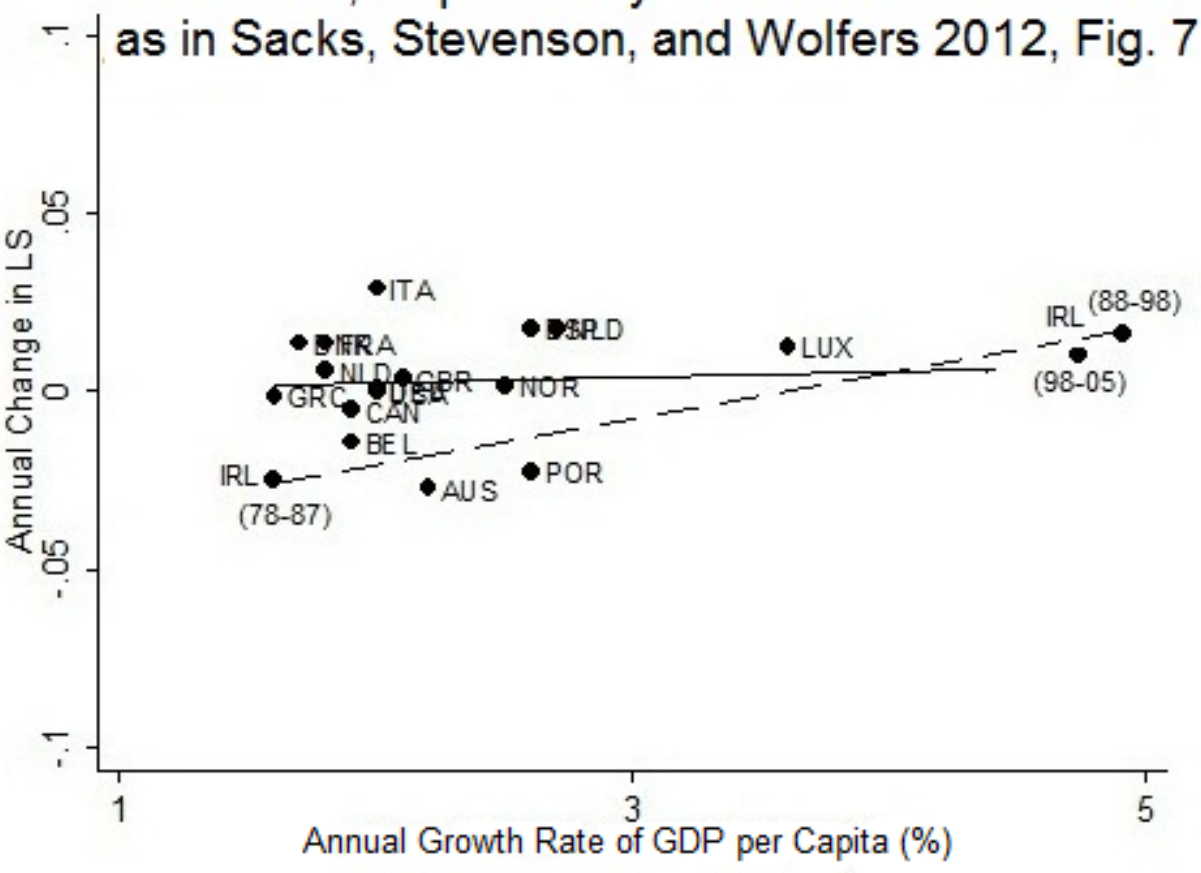


FIGURE 9

Figure 9. Life Satisfaction and Index of Real GDP,

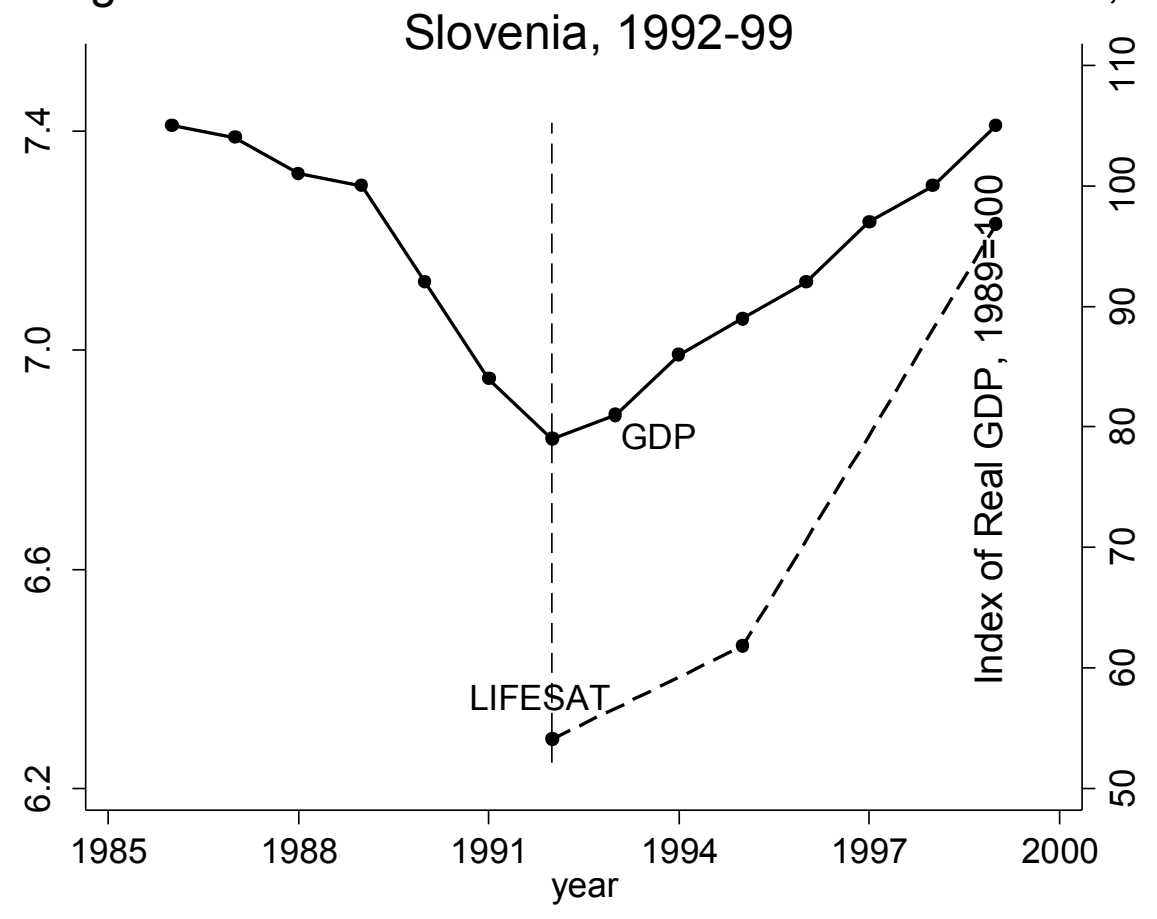


FIGURE 10

Figure 10. Happiness and Index of GDP, Slovenia and Six Countries with Early Life
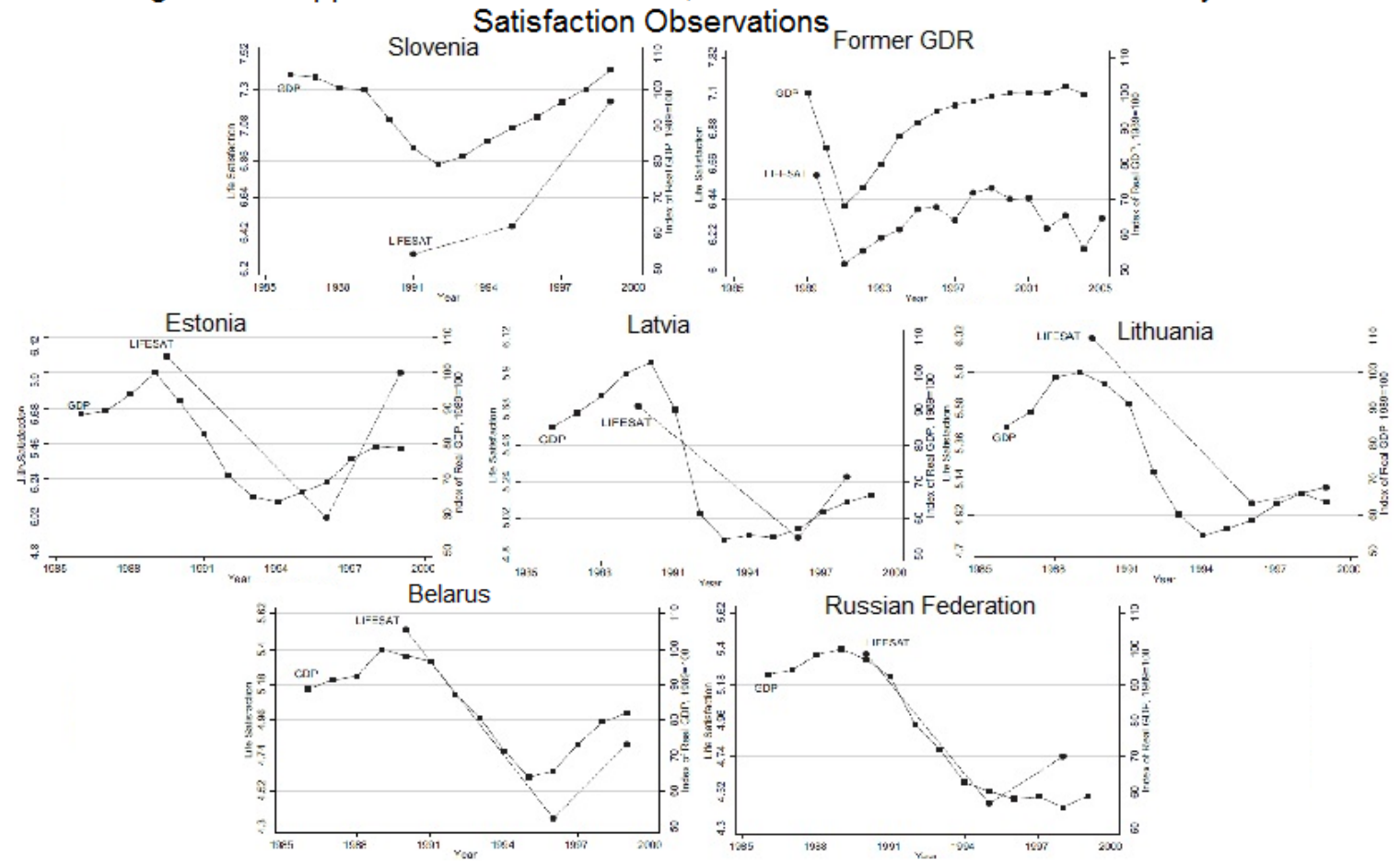
FIGURE 11

Figure 11. Unemployment Rate, Specified Country,

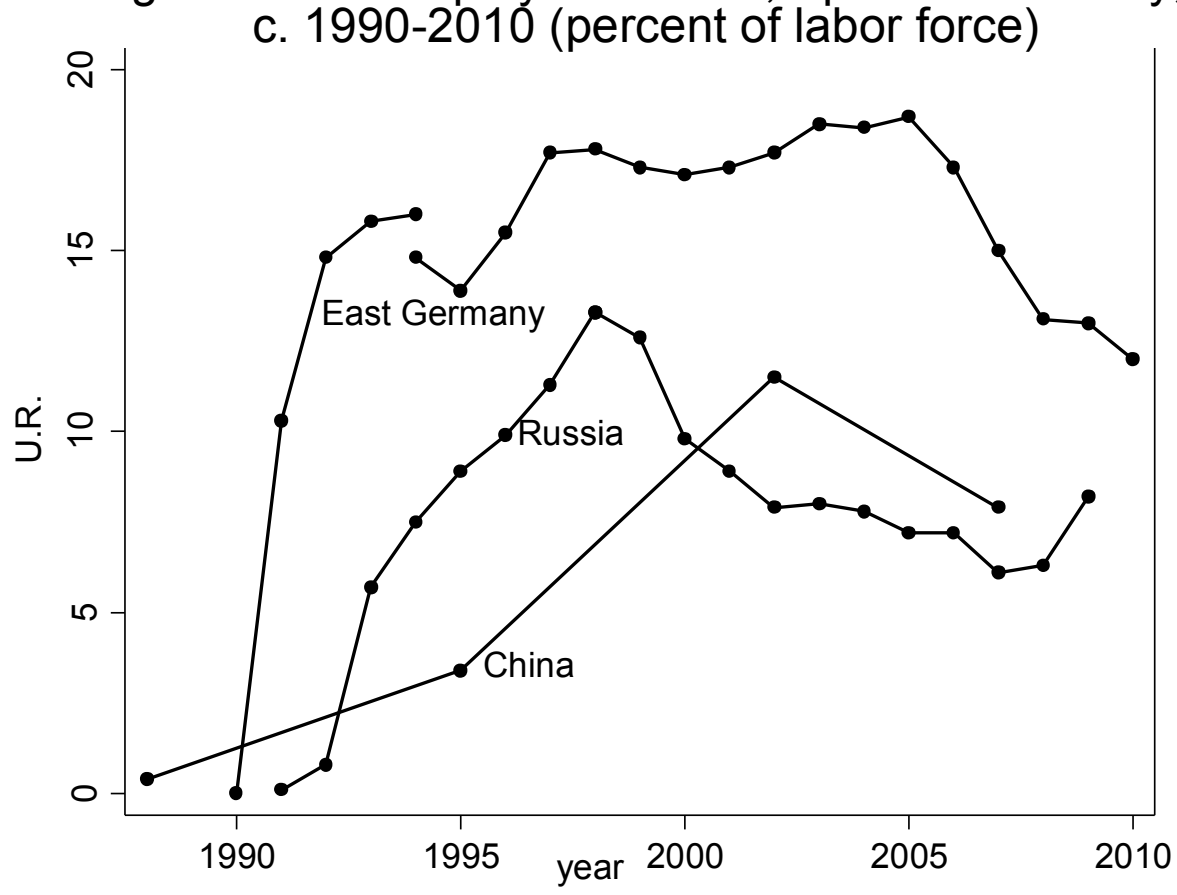


Captions for Figures:

Figure 1.

Source: The figure and title are reproduced from: Deaton 2008, p. 57. Each circle is a country, with diameter proportional to population.

Figure 2.

Note: The fitted regression is $\mathrm{y}=-0.001+0.002 \mathrm{x}\left(\mathrm{adj} . \mathrm{R}^{2}=0.006\right)$; $\mathrm{t}$-stats in parentheses. $(-0.005)(0.31)$

NS here and in subsequent figures means the slope coefficient is not significant at the .05 level.

Source: Easterlin 2010, p. 117.

Figure 3.

Note: The fitted regression is $y=-0.033+0.004 x\left(\operatorname{adj} . \mathrm{R}^{2}=0.168\right)$; $t$-stats in parentheses. (2.24) (-1.19)

Source: Easterlin 2010, p. 117.

Figure 4.

Note: The fitted regression is $\mathrm{y}=-0.025-0.009 \mathrm{x}\left(\operatorname{adj} . \mathrm{R}^{2}=0.229\right)$; $\mathrm{t}$-stats in parentheses.

Source: Easterlin 2010, p. 119. (2.62) (-1.63)

Figure 5.

Note: The fitted regression is $y=-0.018-0.003 x\left(\operatorname{adj} . R^{2}=0.069\right) ; t-s t a t s$ in parentheses. (3.07) $(-1.61)$

Source: Easterlin 2010, p. 119.

Figure 6.

Note: The fitted regression is $y=-0.012-0.225 \mathrm{x}\left(\operatorname{adj} . \mathrm{R}^{2}=-0.05\right)$; $\mathrm{t}-\mathrm{stats}$ in parentheses.

Source: Easterlin et al 2010, Table S1.

Figure 7.

Sources: WVS-World Values Survey (www.worldvaluessurvey.org), AB-Asiabarometer (www.asiabarometer.org), Gallup (www.gallup.com), Horizon Research (www.agmr.com/members/horizon.html), PEW

(http://www.pewglobal.org/category/datasets/).

Figure 9.

Source: Easterlin 2010, p. 91.

Figure 10.

Source: Easterlin 2010, pp. 88-91. 
Figure 11.

Source: East Germany. 1990, GSOEP (Haisken-DeNew and Frick 2005); 1991-94: ILO; 19942009, Federal Statistical Office of Germany. Russian Fed: ILO, except 2009, World Development Indicators. China: Knight and Xue 2006, extended to 2007 via email from Knight to author. 


\section{FOOTNOTES}

${ }^{1}$ See e.g., Helliwell et al 2012; Stiglitz, Sen, and Fitoussi 2008

2 Fuchs 1983, 14; McCloskey 1983, 514

${ }^{3}$ See also Frey and Stutzer 2002; Veenhoven 1991; Inglehart 2002

${ }^{4}$ For details see Easterlin and Sawangfa 2010, Appendices B and C; Easterlin et al $2012,112-113$

${ }^{5}$ Chinese Academy of Social Sciences 2011; Knight and Song 2005,;Xu 2011

${ }^{6}$ DiTella, MacCulloch, and Oswald 2001; Easterlin et al 2010

${ }^{7}$ Easterlin and Sawangfa, 2010, p. 202; Easterlin et al 2010, Figs 3 and 4

8 Guriev and Zhuravskaya 2009; Sanfey and Teksoz 2007; Sacks, Stevenson, and Wolfers 2012; Stevenson and Wolfers 2008

${ }_{9}^{9}$ Blanchflower and Oswald 2004; Clark et al 2001; Kassenboehoner and HaiskenDeNew 2009; Winkelmann and Winkelmann 1998

${ }^{10}$ see, e.g., Flavin, Pacek and Radcliff 2011, and references therein

${ }^{11}$ Aspalter 2009; Holzman 2012; Kudo 2012; OECD 2010a; Rofman 2005; Tzannatos and Roddis 1998; Vodopivec and Tong 2008 